\title{
Characteristic of Gasoline Fuels in Indonesia Blend with Varying Percentages of Bioethanol
}

\author{
Bambang Sugiarto ${ }^{1}$, C.Setyo Wibowo ${ }^{1}$, Ardi Zikra ${ }^{1}$, Alva.Budi ${ }^{1}$, Try Mulya ${ }^{1}$ \\ ${ }^{1}$ Department of Mechanical Engineering, Faculty of Engineering, Universitas Indonesia \\ ${ }^{2}$ Pusat Penelitian dan Pengembangan Teknologi Minyak dan Gas Bumi LEMIGAS, Jakarta
}

\begin{abstract}
Indonesia has The National Energy Policy based on the principle of fairness, sustainability, and environmentally friendly, and the creation of national energy security. Start from early 2015 , mandatory of using biofuel as a substitution to fuel or blend on subvention fuel, nonsubvention fuel, industrial, commercial, and power plant sector is implemented by the Government of Indonesia on Ministerial Energy and Mineral Resources Regulation 12/2015. As a biofuel, bioethanol can be used as a fuel substitution for gasoline. Bioethanol is a natural product and manufactured by the fermentation of plants containing sugar and starch. Characteristic physical and chemical of bioethanol near to gasoline. The objective of this research was to determine the effect of bioethanol-gasoline blended fuels on the characteristic physical and chemical. The experimental test was using gasoline with octane number $88,92,98$, and $5 \%, 10 \%, 15 \%, 20 \%$ bioethanol blend. The effect of the bioethanol-gasoline blend on physical and chemical properties is increased research octane number, oxygen content, vapor pressure, and to decrease the heating value. The one of the important parameter for combustion process on gasoline 88 is the final boiling point temperature, with bioethanol blend of $20 \%$ can decrease $7 \%$ of the final boiling point value. Keywords: Gasoline, bioethanol, boilling point, oxydation stability, research octane number
\end{abstract}

\section{Introduction}

Biofuels, such as biodiesel (B-100), bioethanol (E-100) and pure palm oil (O-100) are the most widely used type of alternative fuels. They can increase in economic value, and also do not have a negative on the environment [1]. As a biofuel, bioethanol can be used as a fuel substitution for gasoline. Bioethanol is a natural product and manufactured by the fermentation of plants containing sugar and starch. Characteristic physical and chemical of bioethanol near to gasoline. Using bioethanol-gasoline blended fuel can ease off the air pollution [2]. In other words, under the environmental consideration, using ethanol blended with gasoline is better than pure gasoline because of its renewability and less toxicity.

Looking forward to Indonesia that has The National Energy Policy based on the principle of fairness, sustainability, environmentally friendly, the creation of green energy and national energy security. Start from early 2015 , mandatory of using biofuel as a substitution to fuel or blend on subvention fuel, non-subvention fuel, industrial, commercial, and power plant sector is implemented by the Government of Indonesia on Ministerial Energy and Mineral Resources Regulation $12 / 2015$. This policy successes on reducing the fuel and diesel fuel import, with another good effect increase domestic production of biofuel, create and improve biofuel market in the country, and improve the development of the domestic biofuel industry. Based on that National Energy Policy, economic and environmental considerations in Indonesia, we are interested in studying the effects of ethanol contents in the gasoline-ethanol blended fuel characteristic.

The objective of this research was to determine the effect of bioethanol-gasoline blended fuels on its physical and chemical characteristic. The experimental test was using gasoline with various octane number $(88,92,98)$ and $5 \%, 10 \%, 15 \%, 20 \%$ bioethanol blends.

\section{Materials and Methods}

Tests were carried on the laboratory at Pusat Penelitian dan Pengembangan Teknologi Minyak dan Gas Bumi LEMIGAS, Jakarta. In this study, the experimental methods of analysis physical and chemical properties on bioethanol were refers to Indonesia National Standard 7390/2012 (Table 1).

\footnotetext{
Corresponding author: bangsugi@eng@ui.ac.id
} 
Table 1. Characteristic of Bioethanol.

\begin{tabular}{|c|c|c|c|c|}
\hline \multirow[t]{2}{*}{ Characteristics } & \multirow[t]{2}{*}{ Unit } & \multicolumn{2}{|c|}{$\begin{array}{c}\text { Specs } \\
\text { (SNI } \\
\text { 7390:2012) }\end{array}$} & \multirow[t]{2}{*}{ Methods } \\
\hline & & Min. & Max. & \\
\hline Ethanol Content & $\%$-volume & 99.5 & - & $\begin{array}{c}\text { ASTM D } \\
5501\end{array}$ \\
\hline $\begin{array}{l}\text { Methanol } \\
\text { Content } \\
\end{array}$ & $\%$-volume & - & 0.5 & $\begin{array}{c}\text { ASTM D } \\
5501 \\
\end{array}$ \\
\hline Water Content & $\%$-volume & - & 0.7 & $\begin{array}{c}\text { ASTM D } \\
1744 \text { / D } \\
6304 \\
\end{array}$ \\
\hline $\begin{array}{l}\text { Denatonium } \\
\text { Benzoat Content }\end{array}$ & $\mathrm{mg} / \mathrm{L}$ & 4 & 10 & $\begin{array}{c}\text { ASTM D } \\
7304 \\
\end{array}$ \\
\hline $\begin{array}{l}\text { Copper Content } \\
(\mathrm{Cu})\end{array}$ & $\mathrm{mg} / \mathrm{kg}$ & - & 0.1 & $\begin{array}{c}\text { ASTM D } \\
1688 \\
\end{array}$ \\
\hline $\begin{array}{l}\text { Acid as Acetic } \\
\text { Acid }\end{array}$ & $\mathrm{mg} / \mathrm{L}$ & - & 30 & ASTM 1613 \\
\hline $\begin{array}{l}\text { Visual } \\
\text { Appearance }\end{array}$ & & $\begin{array}{r}\text { Cle } \\
\text { L } \\
\text { No D } \\
\text { an } \\
\end{array}$ & $\begin{array}{l}\text { and } \\
\text { ht, } \\
\text { posits } \\
\text { Dirt }\end{array}$ & $\begin{array}{c}\text { Visual } \\
\text { Observation }\end{array}$ \\
\hline $\begin{array}{l}\text { Cloride Ions } \\
\text { Content }\left(\mathrm{Cl}^{-}\right) \\
\end{array}$ & $\mathrm{mg} / \mathrm{L}$ & - & 20 & $\begin{array}{c}\text { ASTM D } \\
512 \\
\end{array}$ \\
\hline $\begin{array}{l}\text { Sulfur Content } \\
\text { (S) }\end{array}$ & $\mathrm{mg} / \mathrm{L}$ & - & 50 & $\begin{array}{c}\text { ASTM D } \\
5453 \\
\end{array}$ \\
\hline $\begin{array}{l}\text { Washed Gum } \\
\text { Content }\end{array}$ & $\mathrm{mg} / 100 \mathrm{~mL}$ & - & 5 & $\begin{array}{c}\text { ASTM D } \\
381\end{array}$ \\
\hline
\end{tabular}

Table 2. Characteristic of Gasoline 88

\begin{tabular}{|c|c|c|c|c|}
\hline \multirow[b]{2}{*}{ Characteristics } & \multirow[b]{2}{*}{ Unit } & \multicolumn{2}{|c|}{ Specs } & \multirow[b]{2}{*}{ Methods } \\
\hline & & Min & Max. & \\
\hline $\begin{array}{l}\text { Research Octane } \\
\text { Number (RON) }\end{array}$ & & 88.0 & 0 & D 2699 \\
\hline Oxidation Stability & Menit & 360 & - & D 525 \\
\hline \multicolumn{5}{|l|}{ Distillation } \\
\hline $\begin{array}{l}10 \% \text { vol. } \\
\text { Evaporation }\end{array}$ & ${ }^{\circ} \mathrm{C}$ & - & 74 & \\
\hline $\begin{array}{l}50 \% \text { vol. } \\
\text { Evaporation }\end{array}$ & ${ }^{\circ} \mathrm{C}$ & 75 & 125 & \\
\hline $\begin{array}{l}90 \% \text { vol. } \\
\text { Evaporation }\end{array}$ & ${ }^{\circ} \mathrm{C}$ & - & 180 & D 86 \\
\hline End Point & $\begin{array}{l}{ }^{\circ} \mathrm{C} \\
\%-\end{array}$ & - & 215 & \\
\hline Residue & $\begin{array}{c}\text { volum } \\
\mathrm{e}\end{array}$ & - & 2 & \\
\hline Density $\left(15^{\circ} \mathrm{C}\right)$ & $\mathrm{kg} / \mathrm{m}^{3}$ & 715 & 770 & $\begin{array}{l}\text { D 4052or } \\
\text { D } 1298 \\
\end{array}$ \\
\hline
\end{tabular}

The experimental methods of analysis physicalchemical characteristic on gasoline were refers to Indonesia Oil and Gas Regulation for example gasoline 88, 92, and 98 (Table 2, 3, 4).

Table 3. Characteristic of Gasoline 92

\begin{tabular}{lcccc}
\hline \multirow{2}{*}{ Characteristics } & \multirow{2}{*}{ Unit } & \multicolumn{2}{c}{ Specs } & \multirow{2}{*}{ Methods } \\
\cline { 3 - 4 } & & Min. & Max. & \\
\hline $\begin{array}{l}\text { Research Octane } \\
\text { Number (RON) }\end{array}$ & & 91.0 & 0 & \multirow{2}{*}{ D 2699 } \\
\hline Oxidation Stability & Menit & 480 & - & D 525 \\
\hline Distillation & & & & \\
10\% vol. Evaporation & ${ }^{\circ} \mathrm{C}$ & - & 70 & \\
50\% vol. Evaporation & ${ }^{\circ} \mathrm{C}$ & 77 & 1110 & \multirow{2}{*}{ D 86} \\
90\% vol. Evaporation & ${ }^{\circ} \mathrm{C}$ & 130 & 180 & \\
End Point & ${ }^{\circ} \mathrm{C}$ & - & 215 & \\
Residue & ${ }^{\%} 0^{-}$ & - & 2 & \\
\hline
\end{tabular}

\begin{tabular}{llllc}
\hline Density $\left(15^{\circ} \mathrm{C}\right)$ & $\mathrm{kg} / \mathrm{m}^{3}$ & 715 & 770 & $\begin{array}{c}\mathrm{D} 4052 \text { or } \\
\mathrm{D} 1298\end{array}$ \\
\hline
\end{tabular}

Table 4. Characteristic of Gasoline 98

\begin{tabular}{|c|c|c|c|c|}
\hline \multirow{2}{*}{ Characteristics } & \multirow{2}{*}{ Unit } & \multicolumn{2}{|c|}{ Specs } & \multirow{2}{*}{ Methods } \\
\hline & & Min. & Max. & \\
\hline $\begin{array}{l}\text { Research Octane } \\
\text { Number (RON) }\end{array}$ & & 95.0 & 0 & D 2699 \\
\hline Oxidation Stability & Menit & 480 & - & D 525 \\
\hline \multicolumn{5}{|l|}{ Distillation } \\
\hline $10 \%$ vol. Evaporation & ${ }^{\circ} \mathrm{C}$ & - & 70 & \\
\hline $50 \%$ vol. Evaporation & ${ }^{\circ} \mathrm{C}$ & 77 & 1110 & \\
\hline $90 \%$ vol. Evaporation & ${ }^{\circ} \mathrm{C}$ & 130 & 180 & D 86 \\
\hline End Point & ${ }^{\circ} \mathrm{C}$ & - & 215 & \\
\hline Residue & $\begin{array}{c}\%- \\
\text { volume }\end{array}$ & - & 2 & \\
\hline Density $\left(15^{\circ} \mathrm{C}\right)$ & $\mathrm{kg} / \mathrm{m}^{3}$ & 715 & 770 & $\begin{array}{l}\text { D } 4052 \text { or } \\
\text { D } 1298\end{array}$ \\
\hline
\end{tabular}

The experimental methods focus of blending between gasoline 88, 92, 98 with bioethanol (E-0, E-5, E-10, E15, E-20), also testing all sample for parameter test octane number, distillation, density, oxidation stability, reid vapor pressure.

\section{Results and Discussion}

The bioethanol used in this study is denatured bioethanol for gasohol. Bioethanol can be used as a gasoline blend because it is easy to mix and has physical and chemical properties close to gasoline. Biofuel specifications of the bioethanol were determined as ASTM standard refers to Indonesia National Standard 7390/2012 and gasoline specifications refer to specification fuels from Indonesian Government.

The result of characteristics fuels after blended as follows :

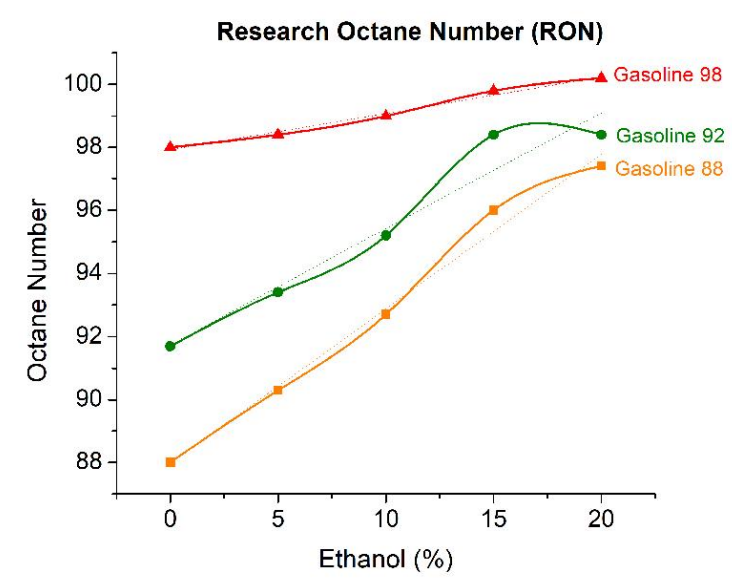

Fig. 1. Octane Number vs Percentages of Bioethanol Added

Octane number is important parameter test for an effect to combustion, to decrease the octane number of combustion SI Engine can occur knocking. Figure 1 appeared blended bioethanol from $0-20 \%$ of gasoline 98 can increase octane number to $2 \%$, gasoline 92 to $7 \%$ and gasoline 88 to $11 \%$. The effect of blended bioethanol with gasoline will more significance for characteristic

*Corresponding author: bangsugi@eng@,ui.ac.id 
octane number if the base gasoline had lower octane number. Octane number is result test with CFR (cooperative fuel research) engine, in the market gasoline had octane number start from 88 until 101, The testing scale this method with RON start from 40 until 120[7]. The use of bioethanol becomes an alternative for booster octane number fuel to need a modern engine with high compression ratio engines, can increase efficiency of the engine with to increase compression ratio[5]. The objective of $\mathrm{RON}$ is the measure of blended bioethanol forward resistance to auto-ignition in the engine with comparing the mixture iso-octane and nheptane, controlled value compression ratio. The measure of the tendency blended bioethanol with gasoline to knock in an SI engine. [6]. Low octane gasoline fuel can causes difficulties in the ignition and the occurrence of delay in acceleration [4].

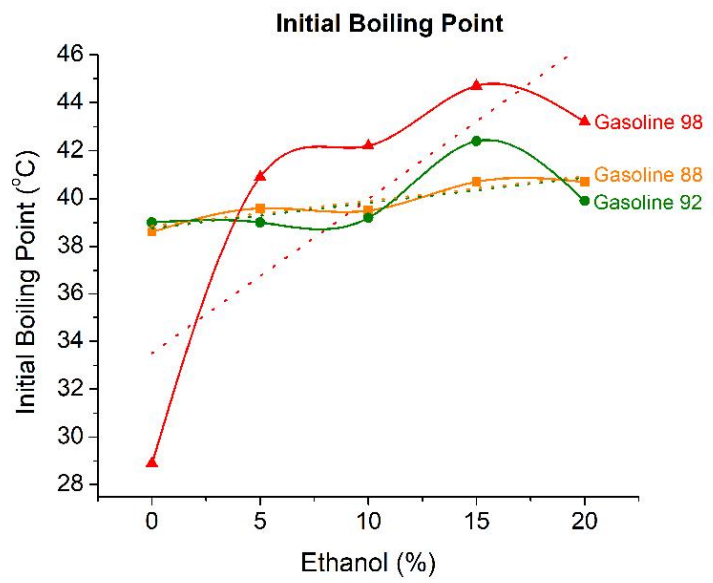

Fig. 2. Initial Boiling Point vs Percentages of Bioethanol Added

Distillation test is an indication of characteristic the convenience volatility gasoline and connected to combustion of performance SI engine. The effect of value degree on initial boiling point connected to combustion of start engine [6]. The blended bioethanol to vary gasoline of reacting to changes and each gasoline had result different. It affects because of different the hydrocarbon content from process distillation the crude oil. The result of an initial boiling point after the blended bioethanol shows at figure 2, with the description among others: blending bioethanol with $20 \%$ volume for gasoline 88 increasing temperature to $5 \%$, gasoline 92 increasing temperature to $2 \%$, gasoline 98 increasing temperature to $49 \%$. Gasoline 98 had the high effect, because the base of this gasoline from a light fraction of distillation from crude oil.

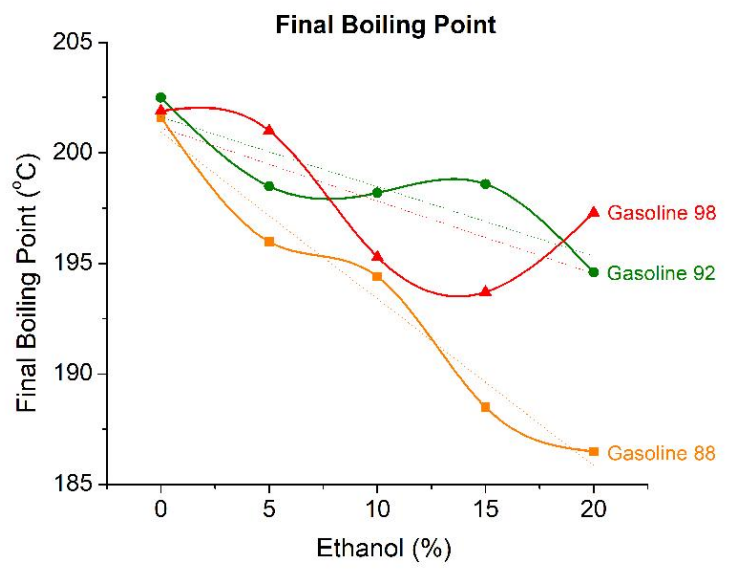

Fig 3. Final Boiling Point vs Percentages of Bioethanol Added

The effect of value degree on final boiling point connected to good combustion of operation engine [6]. The blended bioethanol to vary gasoline of reacting to changes and each gasoline had result different. It affects because of different the hydrocarbon content from process distillation the crude oil. The result of an initial boiling point after the blended bioethanol shows in figure 3 , the trending of temperature final boiling point decreasing after blended bioethanol, with the description among others: blending bioethanol with $20 \%$ volume for gasoline 88 decreasing temperature to $7 \%$, gasoline 92 decreasing temperature to $4 \%$, gasoline 98 decreasing temperature to $2 \%$. Gasoline 88 had the high effect, because the base of this gasoline from a heavy fraction of distillation from crude oil, with decreasing temperature of final boiling point causing the better combustion of SI engine.

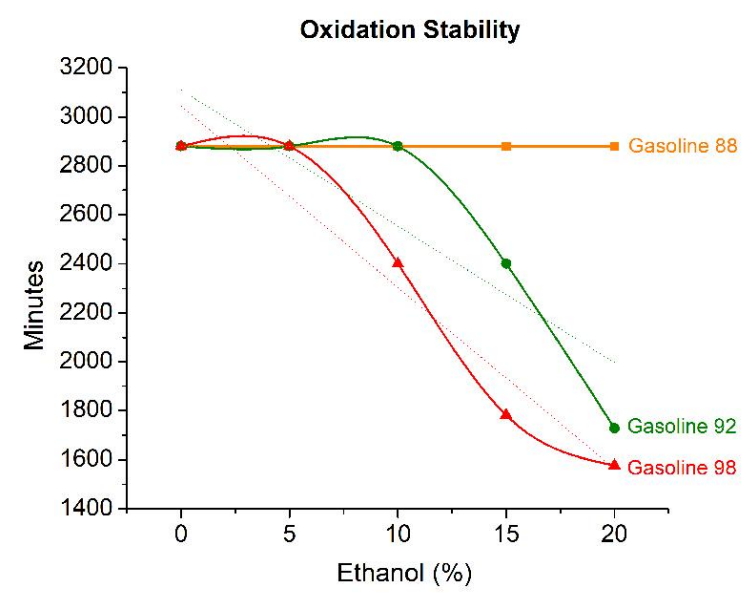

Fig. 4. Oxidation Stability vs Percentages of Bioethanol Added

Oxidation Stability is testing for a speed of oxidation gasoline and blended bioethanol [9]. The effect of parameter oxidation stability of fuels is handling and storage to use tank vehicle. if the value of oxidation stability very law can increase sediment and not good for fuels for the combustion engine. Figure 4 explained with blended bioethanol to $20 \%$ for gasoline 88 is not effected, gasoline 92 decreasing to $40 \%$ and gasoline 98 
decreasing to $45 \%$. Its need continues research for value oxidation stability impact to blended bioethanol.

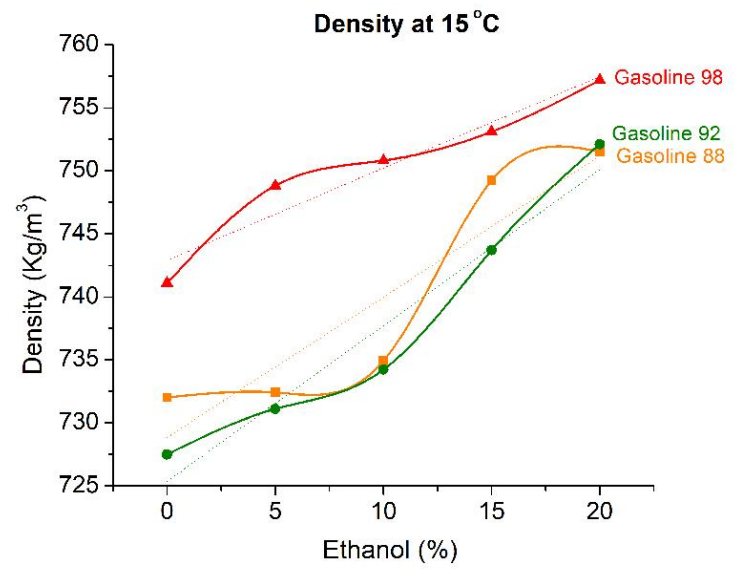

Fig. 5. Density vs Percentages of Bioethanol Added

Density, $n$-mass per unit volume at a specified temperature. Density is a fundamental physical property that can be used in conjunction with other properties to characterize both the light and heavy fractions of petroleum and petroleum products[8]. Figure 5 explained with blended bioethanol to $20 \%$ for gasoline 88 increasing the density value to $3 \%$, gasoline 92 increasing to $3 \%$, and gasoline 98 increasing to $1 \%$. This can occur due to the chemical compounds present in bioethanol and effect the fuel after gasoline-bioethanol blends.

\section{Conclusion}

Blending gasoline fuel with various percentages volume of bioethanol can increase the value of octane number, density, and initial boiling point. But in the other hand, the bioethanol content available on the blended fuel can decrease its oxidation stability. Optimal increasing octane number to $11 \%$ on gasoline 88 , optimal increasing the value of the initial boiling point to $29 \%$ but decreasing the oxisation stability to $25 \%$ on gasoline 98. This chemical and physical changes in this blended fuel may affect the combustion properties later.

This research was supported by PITTA grant on contract number :2393/UN2.R3.1/HKP.05.00/2018,Universitas Indonesia.

\section{References}

[1] Kim H, Choi B. 2008. Effect of ethanol-diesel blend fuels on emission and particle size distribution in a commonrail direct injection diesel engine with warmup catalytic converter. J Renew Energy. 33(10): 2222-8.

[2] Ozcelik A, Aydogan H, Acaroglu M. 2015. A study of the effects of bioethanol-gasoline blends on vehicle emissions. J Clean Energy Technologies. $3(5)$.

\footnotetext{
Corresponding author: bangsugi@eng@ui.ac.id
}

[3] Kima H, Choia B. 2008. Effect of ethanol-diesel blend fuels on emission and particle size distribution in a common-rail direct injection diesel engine with warm-up catalytic converter. J Renewable Energy. $33: 2222-2228$

[4] Osman HA. 2016. Experimental Study The Effect Of Octane Number On Performance Of The Spark Ignition Engine. $J$ Modern Trends Engineering Research. 03 (06).

[5] Juan E. Tibaquirá 1, José I. Huertas 2,* ID , Sebastián Ospina 1, Luis F. Quirama 1 and José E. Niño 2, The Effect of Using Ethanol-Gasoline Blends on the Mechanical, Energy and Environmental Performance of In-Use Vehicles, Energies, 2018

[6] ASTM D 86, Standard Test Method for Distillation of Petroleum Products at Atmospheric Pressure, 2011

[7] ASTM D 2699, Standard Test Method for Research Octane Number of Spark-Ignition Engine Fuel, 2012

[8] ASTM D 4052, Density and Relative Density of Liquids by Digital Density Meter, 2002

[9] ASTM D 525, Standard Test Method for Oxidation Stability of Gasoline (Induction Period Method), 2005 